\title{
Business Combinations, Goodwill and Deferred Taxes: Evidences Emerging From a Comparative Analysis Between Italy and Bulgaria
}

\author{
Gianfranco Capodaglio, Lauretta Semprini \\ Alma Mater Studiorum University of Bologna, Bologna, Italy \\ Vanina Stoilova Dangarska \\ University of National and World Economy, Sofia, Bulgaria
}

\begin{abstract}
The starting point for the research was the evidence of a possible contradiction in the provisions of IAS 12 on goodwill and deferred income taxes, i.e., about the need to calculate deferred income taxation on temporary differences relating to all assets except for goodwill. This paper aims at exploring the degree of consistency between the theoretical provisions of International Accounting Standards (IAS)/International Financial Reporting Standards (IFRS) and their actual application by the management of Italian and Bulgarian listed companies, as regards the accounting treatments of deferred income taxes relating to the item "goodwill". The findings suggest that there are some differences between the accounting methods used by the management of most Italian listed companies and the provisions of IAS/IFRS. It can be argued that the rules given by IAS/IFRS are sometimes contradictory, since they may cause doubts in interpretation. As a consequence, in the end of the paper, an amendment to the provisions, set forth in IAS/IFRS concerning the accounting treatment of deferred income taxes relating to the item "goodwill", is proposed.
\end{abstract}

Keywords: goodwill, deferred taxes, business combination

\section{Introduction}

The content of this paper results from a tradition of research by a study group at the University of Bologna the authors belong to. The studies have focused on the nature of the item "goodwill" and its accounting and tax treatment both in separate and consolidated financial statements. ${ }^{1}$ As is known to all, the European legislation

Gianfranco Capodaglio, full professor of accounting, School of Economics, Management and Statistics, Alma Mater Studiorum University of Bologna; chartered accountant and auditor at Capodaglio \& Associates, Bologna, Italy.

Lauretta Semprini, Ph.D., School of Economics, Management and Statistics, Alma Mater Studiorum University of Bologna, Bologna, Italy.

Vanina Stoilova Dangarska, Ph.D. student, Department of Accountancy and Analysis, Faculty of Finance and Accountancy, University of National and World Economy, Sofia, Bulgaria; chartered accountant and auditor at Capodaglio \& Associates, Bologna, Italy.

Correspondence concerning this article should be addressed to Gianfranco Capodaglio, via Marsala n. 32, 40126 Bologna (BO), Italy. E-mail: g.capodaglio@capodaglioeassociati.com.

${ }^{1}$ One first result of this research is represented by the report by Vanina Stoilova Dangarska during the international conference of 10th Interdisciplinary Workshop on Intangibles, Intellectual Capital and Extra-financial Information, organized by EIASM in Ferrara, Italy, on September 18th to 19th, 2014 and by the report by Lauretta Semprini during the international conference La dimensioneetico-valorialenelgovernodelleaziende (The Ethical and Values Dimension in the Governance of Companies) organized by SIDREA in Palermo, Italy, on September 25th to 26th, 2014. 
requires the adoption of International Accounting Standards (IAS)/International Financial Reporting Standards (IFRS) only for consolidated financial statements of some companies of EU-member states, while for other companies, the adoption of international standards is optional. Therefore, in most EU-member states, there are two sets of accounting standards: the national ones and the international ones. In some previous studies, the Italian accounting standards applied to financial statements as of 31-12-2013 have been compared with IAS/IFRS, thus showing a substantial difference from the accounting treatment of deferred income taxes in business combinations which give rise to goodwill. ${ }^{2}$

Deferred income taxes of Italian financial statements have been subject to an evolving process in recent years, which can be summarized as follows:

(1) In the legislation in force until 31st December, 2003, they were not explicitly considered, while this issue was broadly discussed among scholars and in practice, in application of the accrual basis of accounting. The majority of companies, however, did not consider the important topic of deferred taxes;

(2) The Legislative Decree No. 6 of 17th January, 2003 introduced the Company Law Reform for Italian companies, in compliance with the law of 3rd October, 2001. It amended some articles of the Civil Code and required the recognition of all deferred income taxes in the balance sheets of Italian companies. More specifically, deferred tax liabilities shall be recognized among the provisions for risks and charges, while deferred tax assets shall be recognized in the item No. 4-ter (deferred tax assets), right after the item No. 4-bis entitled "tax receivables" of the statutory scheme of the balance sheet in art. 2424 of the Civil Code. Similarly, the statutory scheme of income statement in art. 2425 of the Civil Code includes the item No. 22 relating to current, deferred, and prepaid income taxes;

(3) Finally, the adoption by the European Union of the Regulation (EC) No. 1606/2002 of the European Parliament and the Council required the adoption of IAS for some consolidated financial statements. Among these standards, IAS No. 12 deals with the issue of deferred income taxes.

It is now clear that the accounting treatment of tax charges is the same as for all other costs recognized during the year (Capodaglio, 2012); more specifically, it is necessary to identify the tax charges on an accrual basis and to distinguish them from those belonging to future years.

If there were no differences between the net income and the taxable income, the accounting treatment of tax charges would not differ from that of any other costs. Yet, since these differences do exist and they are significant, the taxes resulting from the tax return do not ordinarily correspond to those that should be paid if the taxable income was the same as the net income.

However, in accordance with the accrual basis of accounting, all this would not lead to any practical accounting consequences, if all these differences were "permanent", namely differences which do not reverse in future years. Nevertheless, this is not the case. Most of them arise indeed from the tax legislation in force, according to which some specific revenues and/or costs are neither taxable nor deductible in the same year, when they shall be recognized in the income statement in compliance with accounting standards. Therefore, there are many differences that make the tax return income for a period greater or lower than the respective financial statement income and this shall have an opposite effect in the following financial period.

A completely different phenomenon occurs in extraordinary transactions: Demergers, mergers, and acquisitions, as well as transfers of businesses may involve the recognition of assets and liabilities in financial

\footnotetext{
2 The accounting treatment of goodwill provided by the revised version of the Italian accounting standard No. 25, which was approved in August 2014, is similar to the provisions of IAS 12.
} 
statements whose carrying values may significantly differ from their taxable or deductible values. Nonetheless, the economic and accounting nature of these differences are completely different from that arising from ordinary operations. First, in most cases, they do not reverse in future years, namely they are permanent differences. Second, they do not relate to revenues or costs, but they relate to assets and liabilities recognized in the balance sheet.

The Italian accounting standard No. 25, in the prior version to that of August 2014, deals simultaneously with the two abovementioned issues, without distinguishing them clearly. Yet, deferred income taxes arising from transactions which affect directly the shareholders' equity and do not have any effects on the income statement shall be recognized as deferred tax provisions by reducing the shareholders' equity arisen from the transaction itself. By way of example, these differences arise from:

- revaluation of assets recognized in the balance sheet according to specific laws;

- tax-suspended reserves and funds;

- tax-suspended transfer of businesses.

As a consequence, this standard identifies the tax-suspended transfers of businesses or branches, as typical examples of transactions generating differences which require the recognition of deferred tax provisions. It refers equally to all assets acquired and liabilities assumed within the transaction. Hence, if the tax-suspended transfer includes the item "goodwill", deferred income taxes should be measured on this item, too.

In the Italian accounting standard No. 4, which deals with companies' mergers and demerges, there is a note containing a comparison between the provisions of the Italian accounting standard No. 25 and those of the international standard No. 12, which prohibits the recognition of deferred income taxes on "goodwill" emerging from business combinations.

This research aims at assessing all the possible consequences arising from the differences referred to above in the accounting treatment of goodwill and at investigating the origins of the differences themselves.

The importance of this research stems from the fact that the aforementioned differences between some national and international accounting standards involve alternative and incompatible choices when drafting the financial statements. This may cause difficulties in interpretation for stakeholders. Another objective of the research is therefore to find out a solution which can overcome these difficulties in interpretation.

In the following, the main references to the consulted literature on goodwill and deferred income taxes will be reported. In the third section, the research questions, the assumptions made, and the methodology used will be described. Then, the empirical investigation will be outlined, in order to verify the validity of the assumptions made. Finally, the last two paragraphs will show the findings, draw the conclusions, and formulate new assumptions for further developments.

\section{Literature Review}

The effort to provide an economic definition of goodwill has resulted in different contributions: As Onida (1971) stated, the different notions of goodwill in the economic literature can indeed be examined both under their qualitative and their quantitative aspects (see also Bianchi Martini, 1996).

With regard to the first aspect, some academic scholars move away from the concept of goodwill as a "good", for example, Owens (1923) supported the theory of goodwill as a "good", emphasizing its nature as a "quality" or an "attribute", as well as the ability of the company to generate higher future economic earnings (Dicksee \& Tillyard, 1906; Leake, 1921; Canning, 1929; De Dominicis, 1937; Paton \& Littleton, 1940; 
D’Ippolito, 1946; Amaduzzi, 1948; Zappa, 1950; Onida, 1971; Lee, 1971; Tearney, 1973; Samuelson, 1976; Capodaglio, 2010; 2011).

Some other authors placed the emphasis on the concept of goodwill calculated as the difference between the global economic value of an entity and the fair market value of the entity's assets, less its liabilities (Besta, 1920; Guatri, 1957; Falk \& Gordon, 1977; Baxter, 1993; Santesso, 1994; Bryer, 1995; Johnson \& Petrone, 1998). Capodaglio (2010) asserted that goodwill cannot be identified as a separate element of companies, but as a quality, a feature, or even a condition, and as such absolutely inseparable from the context of reference.

Guatri's definition (1989) of goodwill as a "ghost differential" is a perfect synthesis of this second concept.

However, it is worth pointing out that goodwill is mainly considered as a residual in relation to the other intangible assets, including elements which can hardly be quantified individually. In this contest, the value of goodwill is a synthetic expression of those company's intrinsic abilities, which do not form an identifiable and separable resource or asset, despite being an integral part of its organization.

From a quantitative point of view, numerous efforts have been made to provide an adequate methodology to measure goodwill, in order to obtain an increasingly accurate measure (Romano, 2004).

The notion of goodwill in accordance with international standards is essentially consistent with the concept of goodwill as a residual. In fact, the definition set forth in Appendix A of IFRS 3 (revised) is: "an asset representing the future economic benefits arising from other assets acquired in a business combination that are not individually identified and separately recognised" (European Commission, 2008, p. 613). This document contains then a distinction between internally generated goodwill and goodwill arising from business combinations. Internally generated goodwill results from an efficient company management and a strategic organization of the whole set of assets, including human resources, which is favorable to the company. In accordance with paragraph 49 of IAS 38 ,

Internally generated goodwill is not recognized as an asset because it is not an identifiable resource (i.e., it is not separable nor does it arise from contractual or other legal rights) controlled by the entity that can be measured reliably at cost. (European Commission, 2008, p. 403)

Under paragraph 32 of IFRS 3 (revised), the acquirer shall recognize goodwill as of the acquisition date measured as the excess of (a) over (b) below:

(a) the aggregate of:

(i) the consideration transferred measured in accordance with this IFRS, which generally requires acquisition-date fair value $[. .$.$] ;$

(ii) the amount of any non-controlling interests in the acquiree measured in accordance with this IFRS;

(iii) in a business combination achieved in stages, [...] the acquisition-date fair value of the acquirer's previously held equity interest in the acquiree.

(b) the net of the acquisition-date amounts of the identifiable assets acquired and the liabilities assumed measured in accordance with this IFRS (European Commission, 2008).

As opposed to the provisions for internally generated goodwill, goodwill arising from a business combination must be recognized as an intangible asset in the balance sheet from the moment when the economic entity incurs a cost in order to secure for itself the future economic benefits arising from the acquired set of assets. Capodaglio (2010) pointed out the different accounting treatments of purchased goodwill: On one 
hand, the Italian Civil Code and Italian accounting standards "allow" its recognition, subject to prudential conditions, such as the binding opinion by the Board of Statutory Auditors; on the other hand, international standards "require" its recognition as an asset, subject to subsequent tests.

The initial recognition of goodwill is carried at cost. In fact, under paragraph $65 \mathrm{~B}$ of IFRS 3 ,

If a business combination agreement provides for an adjustment to the cost of the combination contingent on future events, the acquirer shall include the amount of that adjustment in the cost of the combination at the acquisition date if the adjustment is probable and can be measured reliably. (European Commission, 2008, p. 611)

Goodwill is, therefore, considered to be a residual which includes all assets and liabilities that do not meet the conditions for a separate recognition, regardless of their previous recognition of the acquired entity.

As far as subsequent measurements are concerned, it must be firstly stressed that goodwill is allegedly considered to be an intangible asset with an indefinite useful life. This is the reason why goodwill is not subject to amortization, but its value is tested annually for impairment. Therefore, any impairment losses are detected through this procedure, which must be carried out in accordance with IAS $36^{3}{ }^{3}$

Finally, it is necessary to mention the accounting treatment of deferred income taxes relating to goodwill, as described in IAS 12. Under paragraph 19,

With limited exceptions, the identifiable assets acquired and liabilities assumed in a business combination are recognised at their fair values at the acquisition date. Temporary differences arise when the tax bases of the identifiable assets acquired and liabilities assumed are not affected by the business combination or are affected differently. For example, when the carrying amount of an asset is increased to fair value but the tax base of the asset remains at cost to the previous owner, a taxable temporary difference arises which results in a deferred tax liability. The resulting deferred tax liability affects goodwill [...]. (European Commission, 2008, p. 93) ${ }^{4}$

By reading this passage, the arising of "deferred" income taxes would seem to be necessary for all assets acquired and liabilities assumed, whose carrying value differs from the tax base, including goodwill. However, paragraph 21 specifies:

Any difference between the carrying amount of goodwill and its tax base of nil is a taxable temporary difference. However, this standard does not permit the recognition of the resulting deferred tax liability because goodwill is measured as a residual and the recognition of the deferred tax liability would increase the carrying amount of goodwill. (European Commission, 2008, p. 93)

Therefore, international standards provide an exception to the general accounting treatment of deferred income taxes relating to goodwill; this is indeed the core of the present survey.

The examined literature (Amir, Kirschenheiter, \& Willard, 1997; C. C. Bauman, M. P. Baumann, \& Halsey, 2001; Chaney \& Jeter, 1994; Chludek, 2011; Gordon \& Joos, 2004; Lev \& Nissim, 2004; Nobes \& Norton, 1996; Fritz \& Lammle, 2003; Graul \& Lemke, 1976; Hanlon, 2005) does not provide a joint discussion of issues on goodwill and deferred income taxes relating to that. The survey aims at investigating these topics, which have been scarcely discussed in the literature so far.

\footnotetext{
${ }^{3}$ Under paragraph 107 of IAS 38, an intangible asset with an indefinite useful life shall not be amortised. Paragraph 108 provides as "in accordance with IAS 36, an entity is required to test an intangible asset with an indefinite useful life for impairment by comparing its recoverable amount with its carrying amount: (a) annually; (b) whenever there is an indication that the intangible asset may be impaired" (European Commission, 2008, p. 413).

4 The previous paragraph 15 provides as follows: "A deferred tax liability shall be recognised for all taxable temporary differences, except to the extent that the deferred tax liability arises from: the initial recognition of goodwill" (European Commission, 2008, p. 91).
} 


\section{Research Methods}

Starting from the premise that all EU listed companies currently have to apply IAS/IFRS for their consolidated financial statements, it was decided to verify whether in other EU member states there were differences between domestic and international accounting standards which are similar to those in Italy as far as deferred income taxes on goodwill are concerned.

Among the basic research assumptions, the possible origin of these differences in the so-called environmental factors was identified, i.e. the historical, cultural, and social characteristics of the different EU countries (Alexander \& Archer, 2000; Berry, 1987; Černe, 2009; Choi \& Mueller, 1992; Do CéuAlves \& Antunes, 2011; Gernon, 1995; Gray, 1988; Nobes, 1981; 1983; 1998; Hatfield, 1966; Hofstede, 1984; Hopwood, 1987; Mueller, 1967; Nair \& Frank, 1980; Nobes \& Parker, 2004; Seidler, 1967a; 1967b; Saudagaran, 2004). On the basis of that assumption, the possible differences, between domestic accounting standards and IAS/IFRS of a country whose environmental factors were quite different from the Italian ones, were examined. That comparison could have led to three different results:

(1) There are no differences between IAS/IFRS and domestic accounting standards: It was decided to investigate whether the environmental factors of this country are actually different from those of IAS/IFRS countries;

(2) There are similar differences to those identified in Italy: This might mean that the assumptions made are not valid;

(3) There are indeed differences between domestic and international accounting standards, though they are completely different from those identified in Italy; in this case, it was decided to investigate the different historical, cultural, social, and environmental origins among the examined countries.

The choice fell on Bulgaria, also because of the possibility of obtaining the necessary data to carry out the research. Such possibilities are granted by a scientific and educational agreement between Alma Mater Studiorum (University of Bologna) and the University of National and World Economy of Sofia.

As it will be shown later, there are actually differences between the domestic accounting standards of the two countries, though listed companies have to apply exclusively IAS/IFRS both in Italy and Bulgaria. Therefore, it was necessary to wonder whether the accounting treatment of Italian and Bulgarian listed companies was homogeneous or not. If this is the case, it will be interesting to investigate the origins of such differences.

As a second research question, a possible solution, in order to eliminate the significant contradiction in the provisions of IAS 12 on goodwill and deferred income taxes, will be investigated. ${ }^{5}$

Hence, what the consequences of the highlighted differences might be for stakeholders of the financial statement was analyzed. More specifically, depending on the choices made, a significant liability can be recognized in the balance sheet.

In order to verify if there are indeed interpretation uncertainties due to the coexistence of two different sets of accounting standards, an empirical analysis on the accounting treatment of the item goodwill in financial statements of listed companies was carried out, which will be described in the following paragraphs/sections. The research was limited to the period from 2008 to 2011, since it represents the first three years when

\footnotetext{
${ }^{5}$ In compliance with IAS 12, deferred income taxes shall be recognized for temporary differences on all assets, except for the item "goodwill".
} 
international accounting standards have been fully applied in Italy in separate financial statements for listed companies, too.

This research belongs to the studies on international accounting and has a prescriptive and regulatory goal (Zambon, 1996); it is aimed at demonstrating that the accounting treatment of deferred income taxes relating to goodwill required by IFRS does not adequately represent this phenomenon.

As it has been observed, the survey methodology in the field of international accounting consists of three levels: the object analysis mode, the time dimension, and the method for deriving data.

Under this approach, the methodology used in this paper is more specific, since it is aimed at deepening this issue in relation to a single entity, which has been chosen within a reference level, i.e., the listed companies of two countries of the European Union (Italy and Bulgaria). It is also static, as it involves the investigation of a given topic with reference to certain items over a determined period (2008-2010); its starting point is inductive, since it was collected empirical evidence from reality and subsequently it was drawn general conclusions based on a top-down approach in the end.

As already mentioned, this paper belongs to the studies on international accounting and it is based on international accounting issues, concerning multinational economic bodies by their very nature (Zambon, 1996; Di Pietra, 2000).

\section{Development of the Research, Company Sample and Results}

\section{Analysis of the Legislation and Practice}

In compliance with the Italian legislation (art. 2426, n. 6 of the Civil Code), goodwill acquired for consideration ${ }^{6}$ can be recognized in the balance sheet within the limit of the cost incurred, with the consent of the Board of Statutory Auditors, when present, and shall be amortized. As mentioned in the premises, the Italian legislation does not explicitly deal with deferred income taxes relating to goodwill. For this reason, its accounting treatment should not differ from all other technical fixed assets, when the carrying value is different from the value recognized for tax purposes. As already mentioned, Italian accounting standards, and in particular, the accounting standard No. 25 in the revised version, now comply with the provisions of IAS 12 and therefore deferred income taxes relating to goodwill shall not be recognized.

The Italian Civil Code deals with deferred taxation in financial statement's structure. More specifically, under art. 2424, deferred tax assets shall be recognized among the current assets in the item C.II.4-ter "deferred tax assets", while deferred tax liabilities shall be recognized in the item B.2 as deferred tax provisions. The income statement includes the item No. 22 relating to current, deferred, and prepaid income taxes.

In compliance with the tax legislation, the costs relating to goodwill are differently deductible depending on the kind of transaction from which it emerges. When businesses are purchased, goodwill shall be amortized for tax purposes for a period of currently 18 years or more and the depreciation charge of goodwill is always deductible from the tax base. This generally results in temporary differences due to the different depreciation charges, and hence deferred income taxes shall be recognized.

In case of business transfers, mergers, and demergers, in compliance with the general rule of tax legislation, the difference in the values of assets for tax purposes, which correspond to the carrying values

\footnotetext{
${ }^{6}$ It is intended for consideration when arising from transfers, mergers, and demergers.
} 
before the transaction and their carrying values after the transaction, is not deductible from the tax base. ${ }^{7}$ In this second case, these differences are permanent, though in compliance with international and national accounting standards, deferred income taxation shall be recognized for all items, except for goodwill.

As for Bulgaria, the Law on Accountancy does not deal with the accounting treatment of assets, liabilities, costs, and revenues, which shall be governed by the applicable accounting standards. All entities apply international accounting standards, except smaller entities, which meet the quantitative criteria set by law, can apply Bulgarian accounting standards. These standards are sources of law, because they are adopted by Ministerial Decree and are published on the State Gazette.

Also the commercial law does not contain any provisions on goodwill and deferred income taxes arising from transfers, mergers, and demergers.

The Bulgarian tax legislation is similar to the Italian one in many respects, however, it treats the item "goodwill" in a totally different way: the Corporate Income Tax Act, published in the State Gazette (Darjaven Vestnik) No. 105 as of December 22, 2006, which entered in force on January 1, 2007, within the section "Non-recognition of Income and Expenses From Subsequent Valuations (Revaluations and Impairments)", provides (see art. 34): The proceeds and expenditures from subsequent assessment of assets and liabilities shall not be recognized for tax purposes in the year of their accounting (Parliament of the Republic of Bulgaria, 2006). Article 35 provides moreover that any income and expenses from subsequent valuations unrecognized for tax purposes according to the procedure established by article 34 herein shall be recognized for tax purposes in the year of write-off of the relevant asset or liability (Parliament of the Republic of Bulgaria, 2006).

Goodwill shall not be recognized for tax purposes in accordance with the Bulgarian tax legislation. In fact, article 48 defines as tax depreciable assets:

(1) the tax tangible fixed assets;

(2) the tax intangible fixed assets;

(3) the investment properties, with the exception of land;

(4) the subsequent expenses referred to in article 64 herein.

Article 49 expressly states that goodwill generated as a result of a business combination shall not be a tax depreciable asset and that any loss from impairment and upon write-off of goodwill shall not be recognized for tax purposes (Parliament of the Republic of Bulgaria, 2006).

These provisions are particularly important for the purposes of this study, considering the legislation in force in Bulgaria regarding the accounting treatment of goodwill. The national accounting standard No. 22 regarding the accounting treatment of business combinations requires indeed the systematic amortization of goodwill over its useful life and the recognition of the amortization charge for each period as an expense by the acquiring entity, contrary to the provisions of international accounting standards.

The result is that goodwill arising from business combinations in Bulgaria affects the income statement through its amortization charges for companies adopting NAS and through any write-downs for IFRS-adopters. However, goodwill is not recognized for tax purposes in both cases.

For the recognition of tax effects of business combination, the national accounting standard No. 22 refers to the national accounting standard No. 12.

\footnotetext{
${ }^{7}$ All this, even if special laws provide the possibility of recognizing any higher values of the assets acquired for tax purposes as a result of these transactions by paying a substitute tax.
} 
In compliance with the national accounting standard No. 12, deferred tax liabilities shall be recognized whenever there are taxable temporary differences. Such differences arise, when the carrying value of an asset or a liability differs from its taxable or deductible value. More specifically taxable temporary differences are defined as temporary differences that will result in taxable amounts in determining taxable profit (or tax loss) of future periods when the carrying amount of the assets or liability is recovered or settled.

Goodwill arising from business combinations is not recognized for tax purposes and the national accounting standard does not provide any exceptions to the recognition of deferred tax liabilities arising from taxable temporary differences. Therefore, it can be argued that Bulgarian accounting standards do not exclude the recognition of deferred income taxes relating to goodwill.

As it will be shown later, the differences between the legislations of these two countries are mainly due to the environmental factors.

From an economic point of view, Bulgaria has only recently moved from a collectivist system to a free market system, while Italy has always been characterized by a market economy model, in spite of going through a 20-year period of corporate system.

Nevertheless both economic structures are made up of small and medium entities and the so-called "micro-entities" represent a great percentage.

The aforementioned differences have led to verify if and to what extent they affect the behavior of the drawers of financial statements, when recognizing the item "goodwill" and presenting it in the financial statement, also in relation to deferred income taxes.

\section{The Empirical Analysis}

Given these assumptions, a quantitative analysis on financial statements of Italian and Bulgarian listed companies was carried out.

This survey covered the financial statements of all listed companies, other than those belonging to financial and insurance sectors; the exclusion is justified by the different natures of these companies, whose inclusion would have led to greater difficulties in interpretation.

The number of companies listed on regulated markets is extremely low; hence it was possible to examine the entire "universe" of data, without the need to select a representative sample.

During the first step of the research, data were collected.

As far as Italy is concerned, it firstly identified all companies listed on the Italian stock exchange over the 2008-2010 period. $^{8}$

As mentioned before, it was decided to acquire the financial statements of all listed companies; the notes were then examined to financial statements, in order to obtain some necessary information for the following steps of our survey.

More specifically, the project was developed in the following way. Of the approximately 350 companies listed on the Italian stock exchange over the years 2008, 2009, and 2010, only those companies whose 2010 financial statements was available (251) were taken into consideration.

The research was then developed with reference to financial statements of companies, whose "goodwill" showed a variation in any of the selected years (i.e., 59 companies). This analysis was restricted to separate

\footnotetext{
${ }^{8}$ Authors chose these financial years mainly taking into account the availability of financial statements at the beginning of our research; however, these periods significantly represent how IAS/IFRS are ordinarily applied in separate financial statements by the management of listed companies, as their application has been required by the Italian law since 2006 .
} 
financial statements, thus excluding the consolidated ones, since they did not influence taxation. ${ }^{9}$

Once, the financial statements containing the aforementioned variation in "goodwill" was identified, the content of the notes was examined, in order to detect whether this variation was caused by business combinations, such as mergers and acquisitions; in these cases, whether and to what extent deferred income tax assets and liabilities referring to the business combination were recognized were examined.

In the course of this paper, the cases will be described, where the recognition of goodwill did not conform to the IFRS, with respect to its accounting treatment, to its subsequent evaluations, and to the recognition of deferred tax assets and liabilities.

As long as Bulgaria is concerned, it was made in a similar way. More specifically, they have selected all Bulgarian listed companies, starting from the tables and reports published on the Bulgarian stock exchange website. In order to obtain quantitative data, it was relied on the website Infostock.bg. As a first approximation, they have taken into account all data relating to listed companies, except for those belonging to financial and insurance sectors. Afterwards, they analyzed only the financial statements of companies that showed a change in the item "goodwill". For all of them, they investigated more deeply the contents of the balance sheets, the income statements, and the notes, as it was previously done for Italy.

Of the approx. 300 companies, only six of them showed a change in the item "goodwill" in their separate financial statements.

The analysis focused on 59 Italian companies, where a variation in the item "goodwill" was noticed and whose financial statements included deferred tax assets or liabilities relating to it. The different categories of the identified accounting treatments of goodwill below were listed.

Category (A). In most cases, the item "goodwill" increases as a result of taxable transactions and consequently deferred tax is recognized. In these cases, temporary differences arise from the different accounting treatment of goodwill required by IFRS and the Italian tax law. Under international standards, goodwill is no longer amortized, but subject to possible impairment losses, whose deduction from the tax base is not allowed by the Italian tax law. On the opposite side, it is possible to deduct from the tax base and the amortization of goodwill, measured with predefined percentages, independently of the financial statements. These companies have thus deducted the amortization of goodwill only in their tax returns and they consequently have to recognize deferred tax liabilities. In some cases, deferred tax assets are measured on goodwill impairments which shall not be deducted from the tax base. All these cases are considerably in line with the provisions contained in the IFRS.

Category (B). The financial statements of three companies contain an explicit and unreserved statement, as required by IFRS 1, of full compliance with IFRSs. Nevertheless, goodwill has been amortized. Indeed, the income statement shows the item "amortization of goodwill" for the years 2009 and 2010. This does not seem to be in line with the provisions of IFRS.

Category (C). In two cases, goodwill arises from mergers. In these cases, deferred income taxes are not recognized for the acquisitions, but then deferred tax assets are recognized relating to the item "amortization of goodwill". The available data show that one of these companies has "released the goodwill" by paying a

9 The consolidated financial statements were necessary to develop another step of this research. In order to understand the reasons why authors only analyzed separate financial statements for these purposes, you can refer to the work of Nobes and Norton (1996). They asserted the existence of three types of goodwill: internally generated goodwill, non-consolidated goodwill, and goodwill on consolidation. Then they pointed out that only separate financial statements can be examined for tax purposes and for this reason only non-consolidated goodwill can be analyzed for taxation. 
substitute tax. This procedure will be analyzed in the following paragraph. The recognition of deferred tax assets could be linked to this fact. However, as for the other company, any explanation on this issue was not found.

Category (D). In one case, deferred tax assets relating to impairment losses are recognized, since they shall not be deducted from the tax base. Deferred tax liabilities relating to amortizations of goodwill are not recognized, since they could be deducted from the tax base in the tax return. From the available data, it is not clear whether the recognized goodwill is relevant for tax purposes or not. In this second case, deferred tax assets relating to the impossibility of deducting goodwill impairment losses from the tax base should not have been recognized.

Category (E). The 2010 financial statement of a company shows "uses of deferred tax provision" relating to goodwill, due to a merger occurred in 2008, since "their depreciation charges were not deductible". In 2010, the management realigns the values of goodwill by paying a substitute tax and therefore all depreciation charges become deductible, without the need to recognize deferred tax liabilities. The origins of deferred income taxes relating to goodwill, which are "used" in 2010, are not clear. Since goodwill was not relevant for tax purposes in the first years, it is not possible to recognize deferred income taxes over the years from 2008 to 2009 relating to depreciation charges deductible from the taxable income, as occurs in category A. This deferred tax provision could be related to goodwill, and this is in contrast with the provisions of IAS 12 . Moreover, the accounting treatment of the substitute tax is not clear.

Category (F). In one case, which is similar to the previous one, the realignment of goodwill occurred in 2010, but goodwill arose in 2002, when IFRS were still not applicable in Italy. The substitute tax is recognized as an asset as an "advance on accrued taxes". Another company too recognizes deferred tax assets relating to the substitute tax.

Category (G). In one case, goodwill is declared to be deductible from the tax base and deferred tax assets are recognized. It is not clear whether goodwill is subject to amortization, and therefore deferred tax assets can arise from the difference between the statutory amortization and the tax amortization. In this second case, the considerations of category B apply.

Category (H). In one case, goodwill results from the acquisition of a business branch and therefore relevant for tax purposes. The deferred tax provision includes the "reversal of goodwill amortization" but there are no explanations. Probably it refers to deferred income taxes relating to the adjustments made on tax return, as already mentioned for category $\mathrm{A}$.

Category (I). The financial statement of one company shows goodwill relating to business acquisitions and therefore relevant for tax purposes. Part of the deferred tax assets relate to non-deductible depreciations. There are not any deferred tax liabilities relating to non-accounting deductions of amortizations.

Category (J). A company declares to adopt the Italian national accounting standards amortizes goodwill and calculates deferred tax on it; it is not clear if deferred tax liabilities ware recognized at the initial recognition of goodwill, non-deductible for tax purposes. This procedure also has some doubts as to interpretation, since, as listed company, should have adopted the international accounting standards.

As for Bulgarian companies, the situation is completely different: Only six financial statements out of 250 companies show variations in the item "goodwill". For all of them, the notes to the financial statement have been analyzed, in order to detect whether the provisions of international standards have been applied correctly, as occurred with the Italian companies. More specifically, the analysis was focused on any possible 
amortization of goodwill, on the existence of any possible deferred tax provisions relating to goodwill which is not deductible from the tax base, and on deferred tax assets or liabilities relating to taxation of depreciation charges and to goodwill value adjustments.

The findings suggest that there are not any deviations from the provisions of international standards. In some notes to the financial statements of the analyzed companies, there is a passage about the arising of goodwill from business combinations, whose carrying amount is not recognized for tax purposes. Here is a literal translation of the abovementioned passage,

This company has originated from the merger with (names of the companies involved). Following this merger, the carrying values of the identifiable assets acquired and the liabilities assumed have increased to their fair values. As a result, taxable temporary differences arise, which lead to deferred tax liabilities. This reflects on the (amount of) goodwill, since the value recognized for tax purposes remains the acquisition value by the previous owner. (Zarneni Hrani Bulgaria AD-Sofia, 2009) $)^{10}$

Therefore, such reasoning is based on the concept that deferred income taxes are recognized for all items of the financial statement affected, except for goodwill, which is considered as a residual.

\section{Findings}

\section{The Influence of Environmental Factors}

As previously mentioned, IFRSs do not allow the amortization of goodwill, but they require it to be subject to a periodic verification of its value. In addition, IAS 12 sets forth a particular accounting treatment for the differences arising from the carrying value of "goodwill" and the corresponding amount recognized for tax purposes. In this case, it is not possible to create a deferred tax provision. Under paragraph 21 of IAS 12, it said that:

Many taxation authorities do not allow reductions in the carrying amount of goodwill as a deductible expense in determining taxable profit. Moreover, in such jurisdictions, the cost of goodwill is often not deductible when a subsidiary disposes of its underlying business. In such jurisdictions, goodwill has a tax base of nil. Any difference between the carrying amount of goodwill and its tax base of nil is a taxable temporary difference. However, this standard does not permit the recognition of the resulting deferred tax liability because goodwill is measured as a residual and the recognition of the deferred tax liability would increase the carrying amount of goodwill. (European Commission, 2008, p. 94)

Finally, under IAS 12 (see paragraph 21A), it said that:

Subsequent reductions in a deferred tax liability that is unrecognised because it arises from the initial recognition of goodwill are also regarded as arising from the initial recognition of goodwill and are therefore not recognised under paragraph 15(a), for example, if in a business combination an entity recognises goodwill of CU100 that has a tax base of nil, paragraph 15(a) prohibits the entity from recognising the resulting deferred tax liability. If the entity subsequently recognises an impairment loss of CU20 for that goodwill, the amount of the taxable temporary difference relating to the goodwill is reduced from CU100 to CU80, with a resulting decrease in the value of the unrecognised deferred tax liability. That decrease in the value of the unrecognised deferred tax liability is also regarded as relating to the initial recognition of the goodwill and is therefore prohibited from being recognised under paragraph 15(a). (European Commission, 2008, p. 94)

\footnotetext{
10 This is the Bulgarian original text: В резултат на създаването на Зърнени храни България АД, чрез сливане, съгласно договор от 21 септември 2007 г., между Сльнчеви льчи България АД, Зърнени храни Трейд АД, Бек Интернешънъл АД, Зърнени храни-Вълчидол АД, Зърнени храни Балчик ЕАД, Зора АД, Прима Агрохим ЕООД и Химимпорт Агрохимикали ЕООД балансовата стойност на придобитите разграничими активи и поети пасиви е увеличена до тяхната справедлива стойност. Вследствие на това възникват облагаеми временни разлики, които водят до отсрочен данъчен пасив, отразяващ се на репутацията, тъй като данъчната им основа остава по цената на придобиване на предходния собственик.
} 
The analysis has pointed out that the financial statements of some Italian listed companies are not completely drawn up in accordance with the provisions of international standards, rather, they show accounting treatments which may not be in line with such standards, if it is based on the information inferable from the financial statements. ${ }^{11}$

This is very important, as all listed companies should have applied the provisions of IAS/IFRS to their financial statement from 2006. It is now worth citing paragraph 16 of IAS 1:

An entity whose financial statements comply with IFRSs shall make an explicit and unreserved statement of such compliance in the notes. An entity shall not describe financial statements as complying with IFRSs unless they comply with all the requirements of IFRSs. (European Commission, 2008, p. 12)

At the end of this analysis, as for the accounting treatment of goodwill and its recognition in the financial statements of Italian listed companies, it is possible to draw the following conclusions: Users of such financial statements may have the impression that an unambiguous and unique treatment does not exist, but instead many companies provide a kind of "personal interpretation" of some provisions of the international standards.

An examination on the financial statements of Bulgarian listed companies, however, did not show any deviation to the accounting treatment required by international standards.

The analysis on the financial statements of Italian listed companies has showed that the management of some of them has disregarded the provisions of IAS/IFRS, whose adoption was introduced by the Italian decree No. 38 of 2005; in order to understand why it happened, it is important firstly to point out that the basics of Italian company law differ greatly from the law of those countries, in which these standards have originated.

Bulgarian, Italian, and international accounting standards are very different because of many factors. One of the most important reasons is surely the difference in the legal systems of the different countries but, before that, it is necessary to point out the cultural differences among Italy, Bulgaria, and the United Kingdom, where international accounting standards which are now applied within the European Union originated (for more details on the different environmental factors which form the basis of the discrepancies of the accounting systems, see also Ball, Kothari, \& Robin, 2009; Baydoun \& Willett, 1995; Bushman \& Piotroski, 2006; Doupnik \& Richter, 2004; Doupnik \& Salter, 1993; 1995; Gray, 1988; Hofstede, 1980; Jaggi \& Low, 2000; Lamb, 1996; La Porta, Lopez-de-Silanes, Shleifer, \& Vishny, 1997; McGee, 2008; Nobes, 1998, 2006; Perera, 1989; Puxty, Willmott, Cooper, \& Lowe, 1987; Saudagaran, 2004; Viganò, 1991; Zysman, 1983). It can be seen that the culture of Mediterranean European and Central European countries has been strongly affected by the Greek and Roman traditions. More specifically the latter can be considered as the foundation for all legal systems based on written laws. The logic which drives the culture of these countries is generally deductive, i.e., it starts from general principles and proceeds coherently towards specific elements. It becomes apparent when analyzing legal systems with a hierarchy of norms. At the top, there are the general ones, which shall be always applied, and then proceeding towards gradually lower levels, there are the specific ones, which shall be applied to specific cases.

\footnotetext{
${ }^{11}$ Four out of the 21 companies showing an increase in the item "goodwill" seem to have a blatant discrepancy with the provisions of IFRS; moreover, in other four cases, there is the probability of such a discrepancy. Therefore, this phenomenon may involve forty per cent of the examined companies.
} 
The situation in the Anglo-American culture is totally different, since it is based on inductive logics and on best practices, which have a regulatory value, although they may vary in time. Case-law is inspired to them: All judgments and sentences represent "binding precedents", which all subsequent judgments shall conform to.

All the accounting systems of the different countries are obviously influenced by cultural differences and by the discrepancies in the legal systems.

More specifically, in countries based on common law, since there are not any written laws, accounting standards issued by bodies established under private law have the status of best practice and so they have a regulatory value.

Conversely, in countries based on civil law, which are based on written laws, accounting standards shall only interpret and integrate the law.

Bulgaria, unlike the United Kingdom, has more varied characteristics. Because of its history, it has a detailed and varied regulatory system, which persists even after the end of its collectivist regime and the entry to the European Union. There is a special Law on Accountancy and domestic accounting standards, which are enacted by the Council of Ministers, have a regulatory value, and are published on the State Gazette. In connection with this system, however, there has been a widespread adoption of international accounting standards also by smaller entities, which can apply domestic standards only as an exception to the general rule.

Italy is a country based on civil law, whose written laws and regulations are binding. In Italy, there is not any specific Law on Accountancy, even though the Civil Code deals with accounting issues and the domestic accounting standards enacted by the Italian Accounting Standard Setter (Organismo Italiano di Contabilità known as OIC) interpret the law.

In conclusion, it can be argued that the choices of the management of Italian and Bulgarian companies are not homogeneous, as far as the object of this survey is concerned, and this is caused by the discrepancies in the laws on accountancy and financial statements. Moreover, international accounting standards are widespread applied in Bulgaria, while in Italy there are two sets of accounting standards, which are applied by different categories of entities. Finally, the origins of such differences are to be found in the environmental factors.

\section{An Alternative Solution}

In order to address the second research question about the possibility of a significant contradiction in the provisions of IAS 12 and its possible overcoming, it will now examine a typical Italian case regarding the accounting treatment of goodwill in business combinations, where the carrying value of goodwill differs from the value recognized for tax purposes: It is indeed referring to the transfer of a business. Unlike what happens when purchasing a company, where all carrying values are taxable or deductible, the transfer of a business is fiscally neutral.

As it is known to all (Dezzani, Pisoni, \& Puddu, 1995), during the setting up of a company and the transactions to increase the share capital, the contributions can be represented by money or other properties or rights. In this second case, if the transferee is a limited company, under article 2343 of the Italian Civil Code, the value of the assets or rights conferred must be assessed by an expert. The amount indicated by the expert is the upper limit of the par value of the shares issued, increased by any possible share premium.

The deed of transfer usually contains the indication of the value attributed to every single asset and liability of the business branch acquired, including the item "goodwill".

In order to fully understand the economic meaning of the item "goodwill" in this kind of operations, it is 
worth noticing that goodwill comes from the calculation of the value of assets and liabilities of a going concern. However, the business acquired is not considered as a result of an algebraic sum, rather it should be regarded as a unitary object of exchange. In other words, the following registration might be considered "theoretically" correct:

- Debit: the total amount of the business transferred;

- Credit: equity.

However, for technical, accounting, and legal reasons, this registration is not acceptable in practice; it does not allow the registration of every single identifiable asset acquired and liability assumed in the balance sheet of the purchaser company. As a consequence, in the transfer deed, there are all the values of assets and liabilities, including the possible goodwill.

The item "goodwill" comes from the difference between the value of the business transferred as a whole and the algebraic sum of every single asset and liability which make it up. Therefore, goodwill can be considered as an "asset acquired for consideration", whose cost refers to a multi-year period with an indefinite duration, in accordance with IFRS.

As previously mentioned, IAS 12 "does not permit the recognition of the resulting deferred tax liability, because goodwill is measured as a residual and the recognition of the deferred tax liability would increase the carrying amount of goodwill" (European Commission, 2008, p. 94).

It is therefore a contradiction with the general accounting principle applicable to all assets, which states that it is necessary to recognize a deferred tax provision, when taxable temporary differences arise. This contradiction is clearly stated within the IAS itself, though it does not provide any solution for the arithmetic reason highlighted above.

In a first approximation, it is possible to suggest a very simple solution, which has surprisingly not been taken into serious consideration yet.

If it is supposed that the accounting treatment of deferred income taxes relating to goodwill was similar to the accounting treatment of deferred income taxes of all assets with a potential increase in value. In this case, it would be enough to add to the value given to goodwill, the value of income taxes on identified differences using the following formula:

$$
\text { deferred tax provision }=\frac{\text { goodwill }}{1-\text { tax rate }} \times \text { tax rate }
$$

It is assumed that the contribution value of the business is net of all liabilities, including those relating to deferred income taxes. Therefore, if the difference between the contribution value and the sum of the assets acquired net of the liabilities assumed had to be considered as "goodwill", this item should also be recognized as a net value, after all deferred income taxes are taken out. In order to measure the gross value and the corresponding provision, it is sufficient to divide the net value by ones' complement of the tax rate.

\section{Conclusions}

In a second approximation, it can be argued that the identified difficulties in the interpretation are caused by the mistake hereafter highlighted. The value attributed to the business by the expert or by the parties should be recognized as a net value. Whatever the method is chosen for the business valuation, the result of it must take into consideration all assets and liabilities relating to the business. If this valuation is based on company's future income or expected cash flows, as generally occurs, these elements must consider net of all 
corresponding taxes.

The provisions of IFRS, though not questioning the total value attributed to the business transferred, require the recognition of a deferred tax provision for the values of assets which are not recognized for tax purposes. At this point, the total amount of liabilities increases, while the value of assets remains the same. Therefore, there is a reduction in the net value of the asset which, compared to the consideration value, generates an increase in the original difference. Under IFRS, this further difference (extra-difference) must be recognized as an increase in goodwill, beyond the value of goodwill which appears in the balance sheet annexed to the transfer deed. Therefore, goodwill arisen from the business combination is caused by the accounts not to be balanced. This "imbalance of accounts" is considered as part of goodwill which does not generate deferred income taxes, in order to avoid any consequent imbalances. The mistake is based on the failure to include the total value attributed to the business combination all liabilities, including any possible deferred tax provisions.

However, this reasoning applies for all items of the balance sheet, not only for goodwill.

If the "contribution balance sheet" does not show any deferred tax provisions, one of the following hypotheses can be proposed:

- There are not any differences between the carrying values and the tax bases of all assets and all liabilities assumed;

- The recognized values are "net values", without deferred income taxes;

- The business valuation is incorrect.

At this point, if the first or the second abovementioned hypothesis occurs, or if the "contribution balance sheet" shows deferred tax assets or liabilities, the purchaser company should not make any adjustments. However, if the business has been incorrectly evaluated (third hypothesis), the management should correct the transfer value, as it occurs when there are material misstatements.

During the evaluation of the business to be transferred and the drawing-up of its financial statement, there are not any practical or logical difficulties in the recognition of the deferred tax provision relating to the item "goodwill". Once assessed the values of the identifiable assets and the liabilities assumed of the business to transfer, taking into consideration all corresponding deferred income taxes, it is necessary to recognize goodwill as the possible excess of the consideration transferred over the net of the amounts of the identifiable assets acquired and the liabilities assumed thus measured. This valuation of goodwill should be considered as a net value; thanks to a simple calculation, it is also possible to get the gross value of goodwill and the amount of the relating deferred tax provision.

In addition, there is another advantage in this reasoning. If goodwill is considered as a "gross value", there would be a higher probability of an impairment loss when testing goodwill for the first time. If the value of goodwill is recognized as a net value, there are lower possibilities of impairment losses, because of the recognition of a deferred tax provision. In fact, the measurement of a business as a "going concern" must take into account the average future earnings, net of all costs and liabilities, thus including deferred tax provisions relating to goodwill.

In conclusion, it is possible to state two principles:

(1) In business combinations where it is possible to identify a "transferor party" and a "transferee party", the contractual price is the consideration value of the transferred business, net of all liabilities. These necessarily include the deferred tax provision relating to goodwill; 
(2) The alleged impossibility of calculating deferred income taxes relating to the item "goodwill", when there is a difference between its carrying value and its tax base, is caused by the mistake in the interpretation explained above. Deferred tax provisions relating to goodwill can be easily measured arithmetically.

The research has shown how important and controversial the issue of the accounting treatment of deferred income taxes on goodwill is. The Italian listed companies that were examined often do not comply with the accounting treatment required by international standards in terms of deferred income taxation on goodwill. Therefore, it can be argued that the accounting treatment provided by IFRS is not completely acceptable, as proved with the arithmetical solution explained above.

However, this paper suffers certainly from some limitations, for instance, the low number of countries under investigation. For this reason, the research could extend to analyze other countries of the European Union or to other items of financial statements, such as brands, in order to investigate whether other listed companies comply with the provisions of international standards.

\section{References}

Alexander, D. J., \& Archer, S. (2000). On the myth of “Anglo-Saxon" financial accounting. The International Journal of Accounting, 25(4), 539-557.

Amaduzzi, A. (1948). Ragioneria generale. Florence: Macri.

Amir, E., Kirschenheiter, M., \& Willard, K. (1997). The valuation of deferred taxes. Contemporary Accounting Research, 14(4), 597-622.

Ball, R., Kothari, S. P., \& Robin, A. (2000). The effect of international institutional factors on properties of accounting earnings. Journal of Accounting and Economics, 29(1), 1-51.

Bauman, C. C., Bauman, M. P., \& Halsey, R. F. (2001). Do firms use the deferred tax asset valuation allowance to manage earnings? The Journal of the American Taxation Association, 23(1), 27-48.

Baxter, W. T. (1993). Assets values: Goodwill and brand names (Reprint of occasional research paper No. 14 of the Chartered Association of Certified Accountants, pp. 1-35, London).

Baydoun, N., \& Willett, R. (1995). Cultural relevance of Western accounting systems to developing countries. Abacus, 31(1), 67-92.

Berry, I. (1987). The need to classify worldwide practices. Accountancy, 100, 90-91.

Besta, F. (1920). La ragioneria. Milan: Vallardi.

Bianchi Martini, S. (1996). Interpretazione del concetto di avviamento. Milan: Giuffrè.

Bryer, R. A. (1995). A political economy of SSAP22: Accounting for goodwill. The British Accounting Review, 27(4), $283-310$.

Bushman, R., \& Piotroski, J. (2006). Financial reporting incentives for conservative accounting. Journal of Accounting and Economics, 42, 107-148.

Canning, J. B. (1929). The economics of accountancy: A critical analysis of accounting theory. New York: The Ronald Press.

Capodaglio, G. (2010). La natura economica dell'avviamento. In L. Marchi and Marasca S. (Eds.), Le risorse immateriali nell'economia delle aziende. Profili di misurazione e di comunicazione (pp. 65-75). Bologna: Il Mulino.

Capodaglio, G. (2011). Principi contabili e di bilancio. Rome: RIREA.

Capodaglio, G. (2012). La fiscalità differita nei conferimenti di complessi aziendali. Rivista italiana di ragioneria e di economia aziendale (RIREA), 112(7-8), 397-401.

Černe, K. (2009). Influential factors of country's accounting system. Development. Ekonomska Istraživanja, 22(2), 90-97.

Chaney, P. K., \& Jeter, D. C. (1994). The effect of deferred taxes on security prices. Journal of Accounting, Auditing \& Finance January, 9(1), 91-116.

Chludek, A. K. (2011). Perceived versus actual cash flow implications of deferred taxes-An analysis of value relevance and reversal under IFRS. Journal of International Accounting Research, 10(1), 1-25.

Choi, F. D. S., \& Mueller, G. G. (1992). International accounting. Englewood Cliffs, New Jersey: Prentice-Hall International.

D'Ippolito, T. (1946). La valutazione delle aziende in avviamento. Milan: Giuffrè.

De Dominicis, U. (1937). Negoziazioni di quote di capitale delle società commerciali. Turin: Utet.

Dezzani, F., Pisoni, P., \& Puddu, L. (1995). Fusioni, scissioni, trasformazioni e conferimenti. Milan: Giuffrè. 
Di Pietra, R. (2000). Ragioneria internazionale e “armonia” contabile. Siena: Cedam.

Dicksee, L. R., \& Tillyard, F. (1906). Goodwill and its treatment (3th ed.). London: Gee \& Co, Printers and Publishers.

Do CéuAlves, M., \& Antunes, E. (2011). International accounting standards in Europe: A comparative study. International Research Journal of Finance and Economics, 61, 64-73.

Doupnik, T. S., \& Richter, M. (2004). The impact of culture on the interpretation of "in context" probability expression. Journal of International Accounting Research, 3(1), 1-20.

Doupnik, T. S., \& Salter, S. B. (1993). An empirical test of a judgmental international classification of financial reporting practices. Journal of International Business Studies, 24, 41-60.

Doupnik, T. S., \& Salter, S. B. (1995). External environment, culture and accounting practice: A preliminary test of a general model of international accounting development. International Journal of Accounting, 30, 189-207.

European Commission. (2008). Regulation No. 1126/2008 adopting certain international accounting standards in accordance with Regulation (EC) No. 1606/2002 of the European Parliament and of the Council (consolidated version 01.01.2014 in English). Brussels: Official Journal of the European Union. Retrieved from http://eur-lex.europa.eu/legal-content/EN/ALL/?uri=CELEX:32008R1126\&qid=1438842855593

Falk, H., \& Gordon, L. A. (1977). Imperfect markets and the nature of goodwill. Journal of Business Finance \& Accounting, 44, 443-463.

Fritz, S., \& Lammle, C. (2003). The International process of accounting standards (Master thesis, International Master Program and Culture, Linkoping University, Sweden).

Gernon, L. (1995). International accounting research: A review of its ecology, contending theories and methodologies. Journal of Accounting Literature, 14, 54-106.

Gordon, E. A., \& Joos, P. R. (2004). Unrecognized deferred taxes: Evidence from the UK. The Accounting Review, 79(1), 97-124.

Graul, P. R., \& Lemke, K. W. (1976). On the economic substance of deferred taxes. Abacus, 12(1), 14-31.

Gray, S. J. (1988). Towards a theory of cultural influence on the development of accounting systems internationally. Abacus, 24(1), 1-15.

Guatri, L. (1957). L'avviamento d'impresa. Un modello quantitativo per l'analisi e la misurazione del fenomeno. Milan: Giuffrè.

Guatri, L. (1989). Il differenziale fantasma: I beni immateriali nelle determinazioni del reddito. Finanza, Marketing e Produzione, 1, 3-61.

Hanlon, M. (2005). The persistence and pricing of earnings, accruals, and cash flows when firms have large book-tax difference. The Accounting Review, 80(1), 137-166.

Hatfield, H. R. (1966). Some variations in accounting practice in England, France, Germany and the United States. Journal of Accounting Research, 4(2), 169-182.

Hofstede, G. (1980). Culture's Consequences: International differences in work-related values. Beverly Hills: Sage Publications.

Hofstede, G. (1984). Cultural dimensions in management and planning. Asia Pacific Journal of Management, 1(2), 81-89.

Hopwood, A. (1987). The archeology of accounting systems. Accounting, organizations and society, 12(3), 207-234.

Jaggi, B., \& Low, P. Y. (2000). Impact of culture, market forces and legal system on financial disclosures. International Journal of Accounting, 35, 495-519.

Johnson, L. T., \& Petrone, K. R. (1998). Is goodwill an asset? Accounting Horizons, 12(3), 293-303.

La Porta, R., Lopez-de-Silanes, F., Shleifer, A., \& Vishny, R. W. (1997). Legal determinants of external finance. Journal of Finance, 52(3), 1131-1150.

Lamb, M. (1996). The relationship between accounting and taxation: The United Kingdom. European Accounting Review, 5(1), 933-949.

Leake, P. D. (1921). Goodwill. Its history, value and treatment in accounts. London: Pitman and Sons Ltd.

Lee, T. A. (1971). Goodwill: An example of will-o'-the wisp accounting. Accounting and Business Research, 1, 318-328.

Lev, B., \& Nissim, D. (2004). Taxable income, future earnings, and equity values. The Accounting Review, 79(4), $1039-1074$.

McGee, R. (2008). Accounting reform in transition and developing economies. New York: Springer.

Mueller, G. G. (1967). International accounting. New York: Macmillan.

Nair, R. D., \& Frank, W. G. (1980). The impact of disclosure and measurement practices on international accounting classification. The Accounting Review, 55, 426-450.

Nobes, C. W. (1981). An empirical analysis of international accounting principles: A comment. Journal of Accounting Research, $19(1), 268-280$. 
Nobes, C. W. (1983). A judgmental international classification of financial reporting practices. Journal of Business Finance and Accounting, 10(1), 1-19.

Nobes, C. W. (1998). Towards a general model of the reasons for International differences in financial reporting. Abacus, 34(2), 162-187.

Nobes, C. W. (2006). The survival of international differences under IFRS: Towards a research agenda. Accounting and Business Research, 36(3), 233-245.

Nobes, C. W., \& Parker, R. (2004). Comparative international accounting (8th ed.). New York: Prentice Hall.

Nobes, C., \& Norton, J. (1996). International variations in the accounting and tax treatments of goodwill and the implication for research. Journal of International Accounting, Auditing \& Taxation, 5(2), 179-196.

Onida, P. (1971). Economia d'azienda. Turin: Utet.

Owens, R. N. (1923). Goodwill in the accounts. The University Journal of Business, 1(3), 282-299.

Parliament of the Republic of Bulgaria. (2006). Corporate income tax act (State Gazette No. 105 as of 22 December 2006, Sofia). Retrieved from http://www.lex.bg/laws/ldoc/2135540562

Paton, W. A., \& Littleton, A. C. (1940). An introduction to corporate accounting standards. Chicago: American Accounting Association.

Perera, M. H. B. (1989). Towards a framework to analyze the impact of culture on accounting. International Journal of Accounting, 24, 42-56.

Puxty, A. G., Willmott, H. C., Cooper, D. J., \& Lowe, A. E. (1987). Modes of regulation in advanced capitalism: Locating accountancy in four countries. Accounting, Organizations and Society, 12(3), 273-291.

Romano, M. (2004). L'impairment test dell'avviamento e dei beni intangibili specifici. Turin: Giappichelli.

Samuelson, R. A. (1976). The concept of assets in accounting theory. Accounting Horizons, 10(3), 147-157.

Santesso, E. (1994). Valutazioni di bilancio: Aspetti economico-aziendali e giuridici. Turin: Giappichelli.

Saudagaran, S. M. (2004). International accounting: A user perspective. Chicago: Thomson.

Seidler, L. J. (1967a). International accounting-The ultimate theory course. The Accounting Review, 42, 775-781.

Seidler, L. J. (1967b). The function of accounting in economic development. Turkey as a case study. New York: F.A. Praeger.

Tearney, M. G. (1973). Accounting for goodwill: A realistic approach. The Journal of Accountancy, 136, 41-45.

Viganò, E. (1991). La ragioneria internazionale. Natura, contenuto e metodo. Rivista dei Dottori Commercialisti, 49, 797.

Zambon, S. (1996). Profili di ragioneria internazionale e comparata. Un approccio per aree tematiche. Padua: Cedam.

Zappa, G. (1950). Il reddito d'impresa. Milan: Giuffrè.

Zarneni Hrani Bulgaria AD-Sofia. (2009). Financial statement 2008. Commercial register of Bulgaria. Retrieved from https://public.brra.bg/CheckUps/Verifications/ActiveCondition.ra?guid=b9bc01646fc54ead9480a5f9160bf60d

Zysman, J. (1983). Government, markets and growth: Financial systems and the politics of industrial change. New York: Cornell University Press. 